\title{
Chapter...
}

\section{The crime of aggression and complementarity}

\author{
Pål Wrange ${ }^{1}$ \\ Published in International Criminal Justice: Law and Practice from the Rome Statute to Its \\ Review, Roberto Bellelli (ed.) (Ashgate, 2010) 591-607
}

\section{Introduction}

The focus of this article is not the law as it is (de lege lata), nor how one would wish it to be (de lege ferenda). Both de lege lata and de lege ferenda are proper modi for a government to speak in. However, governments rarely speculate about what the law might be, but that is an approach that suits my personal temper and interests quite well. ${ }^{2}$

I will take a cue here from an important statement made by an eminent lawyer from Northern Italy, Judge Politi of Trento, who already in the Preparatory Commission of the International Criminal Court (ICC) in 2000 advised us to think about aggression and complementarity. ${ }^{3}$ I will therefore deal with the legal principle of complementarity as provided for in the Preamble, in Article 1 and in Articles 17-19 of the Rome Statute, i.e., briefly that the Court shall exercise its jurisdiction only when there is no state that is willingly and ably investigating or prosecuting the case. But I shall also reflect on the idea of complementarity in a broader sense, namely that international criminal law should be developed and exercised in interplay between domestic and international jurisdictions, and what are the implications of this idea on other issues before the Special Working Group on the Crime of Aggression (SWGCA) of the Assembly of States Parties (ASP). I will venture to speculate a bit about how domestic legislators and jurisdictions might react with or without one or more agreed provisions on the crime of aggression after the Review Conference in 2010.

\section{Complementarity}

The principle of complementarity was not embraced by everyone when it entered the Rome Statute. In fact, many saw it as a way of weakening the Statute of the new court. ${ }^{4}$ However, I believe it fair to say that there is now broad agreement that the principle is a useful and even necessary feature of the Statute. This principle provides a connection between on one end national and on the other end international - or supranational - jurisdictions. It is the link that

\footnotetext{
${ }^{1}$ I would like to thank Claus Kress, Håkan Friman, Jutta Bertram-Nothnagel, Christian Wenaweser, Don Ferencz (for his analysis of the judgment in the House of Lords which I borrow from in footnote 43) and, most of all, Christina Villarino Villo and Nicolaos Strapatsas, for helpful comments. Though I have a different take on the matter, Nico's paper 'Complementarity \& Aggression: A Ticking Time Bomb?' (Draft Presented to the Marie Curie Research Course on International Criminal Law, 2007) - thorough and thought-provoking as all of his work -- has been useful for the elaboration of this piece, even when not cited below.

2 I will allow myself an occasional comment de lege lata in the footnotes, however.

3 PCNICC/2000/WGCA/DP.3 p 3.

4 See John T. Holmes, 'Complementarity: National Courts versus the International Criminal Court' in Antonio Cassese, Paola Gaeta and John R.W.D. Jones (eds), Rome Statute of the International Criminal Court (Oxford: Oxford University Press, 2002), 672 footnote.
} 
forces the ICC and national legal systems to engage with one another, at the judicial as well as sometimes - at the political level. Hence, the most important effect of the provision on the crime of aggression might not be prosecutions in The Hague, but prosecutions, and threat of prosecutions, in local jurisdictions. ${ }^{5}$

Now, if a provision on the crime of aggression would be adopted in accordance with Article 5(2) of the Rome Statute, how would it play out with regard to the principle of complementarity?

To my knowledge, the SWGCA has discussed the principle of complementarity only during the informal meeting at the Liechtenstein Institute at Princeton University in 2004, as I will refer to shortly. ${ }^{6}$ The general feeling of the group was that there was no need for any special provisions on complementarity in relation to the crime of aggression. I agree with that conclusion. But that does not mean that the issue is unproblematic.

The questions I would like to ask in this context is if and under what conditions domestic prosecutions might take place in either of three scenarios, and what might be the problems and issues associated with each of them:

I. The scenario where there is a provision on the crime of aggression and the Court is exercising or is ready to exercise jurisdiction over the situation, but a domestic process is under way.

II. The scenario where there is a provision on the crime of aggression, and that clause provides that the ICC can exercise its jurisdiction only after a decision by the UN Security Council (SC) or some other body, and no such decision is forthcoming. This means that the ICC cannot exercise jurisdiction in such a situation.

III. The scenario where there is no provision on the crime of aggression in the Rome Statute, i.e., a situation in which the ICC is never allowed to exercise its jurisdiction over that crime and when there is no agreed definition.

So, the first two situations occur in a hypothetical world after the Review Conference, when a provision on the crime of aggression has been adopted and such a provision has entered into force, while the third scenario is when no such provision is in force but states still might exercise national jurisdiction over the crime of aggression. Legislators will encounter issues, of course, in drafting and adopting domestic provisions relating to the crime of aggression. But judges and other officials of a court may also be faced with questions, even when there is a national statutory provision: the scope of the domestic provision may be unclear; the domestic statute on the crime of aggression may be challenged as unlawful under international law; and a defendant or others might bring forward arguments for why a national court should not exercise its jurisdiction. Which attitudes might national institutions take under these scenarios? In my efforts to answer these questions, I will come across several legal issues, such as:

1. Whether there are sovereignty or legal policy related bars, like the act of state doctrine or the political questions doctrine;

2. Whether there is universal jurisdiction over the crime of aggression or any other ground to prosecute a foreigner for the crime of aggression;

3. Whether it is probable that domestic courts might find themselves compelled to wait for a decision by the Security Council; and

\footnotetext{
${ }^{5}$ As is well known, the Prosecutor, Luis Moreno Ocampo, has even stated that the best outcome of the ICC would be if it had no work at all, due to national jurisdictions doing their job. 'Paper on some policy issues before the Office of the Prosecutor', II (1), page 4.

${ }^{6} \mathrm{ICC}-\mathrm{ASP} / 3 / 25$, at 345 .
} 
4. Whether the crime is sufficiently clear in international law when there is no definition in the Rome Statute.

Some of these questions - like 1 and 2 - will arise under all scenarios, but I will deal with each under the scenario under which the respective question likely will be most prominent. ${ }^{7}$

\section{Scenario I: The ICC is ready to exercise jurisdiction, but national authorities are being seized of the case}

\section{A. Conditions of Scenario I}

Under this scenario there is a provision on the crime of aggression in the Statute, and either there are no special conditions for the exercise of jurisdiction, or those conditions have been met. Consequently, this is the situation where the Court is ready to go, but there are domestic processes in motion. If the Court is investigating or planning to investigate a case, then it has to consider whether the domestic proceedings would be an obstacle to admissibility, under the principle of complementarity. Article 17(a) of the Rome Statute provides that a case is inadmissible when ' $[\mathrm{t}]$ he case is being investigated or prosecuted by a State which has jurisdiction over it, unless the State is unwilling or unable genuinely to carry out the investigation or prosecution', and the same criterion of willingness and ability applies to the situation where a domestic trial has already taken place or a decision has been taken not to prosecute.

Hence, issues would arise at the domestic level as well as at the level of the ICC.

\section{Issues before National Jurisdictions}

The first issue is whether domestic courts really have prima facie jurisdiction, including rationae materiae and rationae personae. Under this scenario, where the crime is in the Statute, the issue of national jurisdiction rationae materiae might not be controversial. The jurisdiction rationae personae might be challenged, in particular in claims to universal jurisdiction, but it might also be well accepted when the crime has the imprimatur of a definition in the Rome Statute. It will probably be assumed that aggression is an international crime, and that the same rules on jurisdiction apply as for the other international crimes, i.e., universal jurisdiction. At any rate, I will deal with both of those issues a bit later on.

But there will be other difficulties.

(a) Immunities.

The crime of aggression is a leadership crime, so the people prosecuted for the crime of aggression will be leaders, i.e., most likely present or former high public officials of a state. ${ }^{8}$ For leaders, the issue of immunity from domestic prosecutions in foreign courts ${ }^{9}$ will likely be raised. Immunities generally come under two rubrics: substantive (or functional) immunity and

\footnotetext{
7 This is, of course, difficult to predict. For instance, under scenario 3, it is obvious that the lack of an agreed definition will feature prominently in the discussion, but it might very well turn out that the most contentious issue is whether a certain person is covered by procedural immunities or not.

8 Though not necessarily only government officials, unless the precedents from Nuremberg are being restricted. Kevin Jon Heller, 'Retreat from Nuremberg: the Leadership Requirement in the Special Working Group's Definition of Aggression', 18 European Journal of International Law (2007) 477-497.

9 I.e., typically courts other than the courts which have jurisdiction based on the nationality principle.
} 
procedural (or personal) immunity. ${ }^{10}$ The first one means that officers of the state shall never be liable individually for state acts. Domestic courts will probably not feel that this applies to international crimes. ${ }^{11}$

The second type of immunity is the procedural immunity, which entails that some types of officials are immune as long as they hold a certain office, for instance that of a foreign minister or a diplomat posted in a certain country. This type of immunity will normally prevent a state from prosecuting, even for international crimes. In the Arrest Warrant Case before the International Court of Justice (ICJ), the Court concluded that the then Foreign Minister of the Democratic Republic of Congo, Abdulaye Yerodia Ndombasi, was immune before Belgian Courts. The ICJ judgment is correct and authoritative in this respect. ${ }^{12}$ Of course, there is no immunity in the ICCSt., but the renunciation of immunity inter partes in the Rome Statute most likely only applies before the ICC. National jurisdictions typically accept procedural immunity, which thus trumps any right or obligation to prosecute international crimes.

In domestic jurisdictions there might also be national immunities, which protect officials from prosecutions before their own courts. In distinction to procedural immunity for foreign officials, however, domestic immunity is not a valid excuse under international law to not prosecute in cases where there is an international duty to do so.

So, suspects of crimes of aggression may in many cases be protected by immunities. However, even if so protected, prosecutions - or fears for prosecutions - will still have effects on the suspect, who will cautiously refrain from travelling to many places, fearing that there might be an international arrest warrant waiting in a particular country, and not knowing whether the local authorities in that country will or will not accept the traditional notion of procedural immunity that usually shields leaders. Further, an incumbent leader will know that the chances of avoiding prosecution will be much slimmer when he or she is one day out of office. A prosecution will also have political consequences. A prosecuted leader will loose legitimacy,

10 The Latin terms are rationae materiae and rationae personae respectively. Chanaka Wickremasinghe, 'Immunities Enjoyed by Officials of States and International Organizations', in Malcolm D. Evans (ed), International Law (Oxford: Oxford University Press, 2nd ed, 2006) 395-422, at 397; Robert Cryer, Håkan Friman, Darryl Robinson and Elizabeth Wilmshurst, International Criminal Law and Procedure (Cambridge: Cambridge University Press, 2007), 423.See also Nicolaos Strapatsas, 'Complementarity \& Aggression: A Ticking Time Bomb?' (Draft Presented to the Marie Curie Research Course on International Criminal Law, 2007).

11 Principle 5 of the Princeton Principles provides that for 'serious crimes under international law', including crimes against peace, the official position shall not relieve a person of criminal responsibility. 'The Princeton Principles on Universal Jurisdiction', reprinted in Stephen Macedo (ed), Universal Jurisdiction: National Courts and the Prosecution of Serious Crimes Under International Law (Philadelphia: University of Pennsylvania Press, 2004) 18-25, at 22. See also A. Hays Butler, 'The Growing Support for Universal Jurisdiction in National Legislation', in Stephen Macedo (ed), ibid, at 76; Robert Cryer et al, supra note 10, at 432; Virpi Koivu, 'Head of State Immunity $v$. Individual Criminal Responsibility', XII Finnish Yearbook of International Law (2001) 305-330, at 330. Wickremasinghe is a bit more cautious; Chanaka Wickremasinghe, 'Immunities Enjoyed by Officials of States and International Organizations', in Malcolm D. Evans (ed), International Law (Oxford: Oxford University Press, 2nd ed, 2006) 395-422, at 416. The ICJ's conservative assertion in the Arrest Warrant Case that $e$ contrario seems to confirm functional immunity tout court (Judgment, Arrest Warrant of 11 April 2000 (Democratic Republic of the Congo $v$. Belgium), 14 February 2002, para. 61) has been widely and rightly criticised, and could probably be set aside as an obiter dictum with less authority than the stare decisis. Robert Cryer et al, supra note 10, at 437; Dapo Akande, 'International Law Immunities and the International Criminal Court, The American Journal of International Law (2004) 407-433, at 413.

12 See supra note 11, at para. 58. For a slightly different perspective, see Virpi Koivu, 'Head of State Immunity $v$. Individual Criminal Responsibility', XII Finnish Yearbook of International Law (2001) 305-330, at 311. 
and if he or she is unable to travel freely, that will inevitably affect her or his ability to function as a leader.

In addition to immunity, there are other "avoidance techniques" - as Hazel Fox has called them - that might be invoked to prevent a court from exercising its jurisdiction. ${ }^{13}$

(b) The act of state doctrine.

The act of state doctrine builds on the same rational as state immunity, namely that one sovereign should not sit in judgment of another one (par in parem imperium non habet). So, it protects foreign sovereigns. This doctrine probably applies only to acts committed within the territory of that state, ${ }^{14}$ but it is not clear whether an act of aggression corresponds to that requisite. The decision to initiate an act of aggression will most likely be made within the foreign state - in its capital - but on the other hand that decision will take effect abroad, and I therefore expect that the doctrine would not apply. At any event, in the US, the act of state doctrine seems not to have provided a bar to court proceedings in cases of international crimes or breaches of jus cogens, and this has been the case also in other jurisdictions like the UK. ${ }^{15}$ And, of course, the rationale of the act of state doctrine was refuted so elegantly by the Nuremberg tribunal, when they reminded us that crimes against international law are committed by men, not by abstract entities. ${ }^{16}$

(c) The political question doctrine.

Another "avoidance technique" is the political questions doctrine, which comes in many shapes, sometimes called "executive privilege", "non-justiciability" or "judicial restraint". ${ }^{17}$ This doctrine says that some issues are not appropriate for judges to handle. It is often applied to matters of foreign policy, and it essentially serves to protect the own sovereign from embarrassment, since the effect is that judges will refrain from entering into areas that the executive usually wants to have reserved for itself. ${ }^{18}$

These two doctrines - act of state and political questions - are usually based on comity rather than on legal obligations. They frequently interact, and I have no intention of analysing them in any detail, since they are domestic doctrines which look different in different countries. I will, however, briefly cover a few arguments that likely would underpin their application.

\footnotetext{
13 See generally and interestingly, Hazel Fox, 'International Law and Restraints on the Exercise of Jurisdiction by National Courts of States', in Malcolm D. Evans (ed), International Law (Oxford: Oxford University Press, 2nd ed, 2006) 361-394; Nicolaos Strapatsas, supra note 11.

${ }^{14}$ Hazel Fox, supra note 13, at 383.

15 Nicolaos Strapatsas, supra note 11, at 22-23. Please note that when I refer to the act of state doctrine, I mean what Strapatsas calls "the second variant" of that doctrine, namely that "courts of one state will generally refrain from sitting in judgment on acts of a governmental character done by a foreign state within its territory and applicable there" (ibid., at 21).

16 Judgment of the International Military Tribunal, cited from http://avalon.law.yale.edu/imt/judlawch.asp (visited 1 February 2009).

17 See Hazel Fox, supra note 13, at 384 and Nicolaos Strapatsas, supra note 11, at 24-28. For an interesting plea for judicial restraint or 'reluctance' - mainly built on policy - see Michael Kirby, 'Universal Jurisdiction and Judicial Reluctance: A New 'Fourteen Points", in Stephen Macedo (ed), Universal Jurisdiction: National Courts and the Prosecution of Serious Crimes Under International Law (Philadelphia: University of Pennsylvania Press, 2004) 240-259.

${ }^{18}$ It has also been questioned whether it is right to second-guess very difficult decisions of political leaders, decisions taken by people who voluntarily have taken on the arduous task of making difficult choices on our behalf. But the same could be said with even more relevance of military commanders, who often have very little time for deliberation in situations, which ultimately might render accusations of war crimes.
} 
It has often been said that the crime of aggression is the most controversial and politically charged crime. This consideration might speak against independent national prosecutions, particularly in cases where there is no authoritative international decision by an international organ, be it the ICC or the SC. (If, on the other hand, there is an international decision to the effect that an act of aggression has occurred, then the burden on the domestic body would be less heavy, and perhaps it would be emboldened to disregard these doctrines.) We can all imagine events in recent history that could have been subjected to prosecution in The Hague if the Court had been able to exercise jurisdiction, and we can all also imagine that such prosecution might have produced great political havoc. But is that unique to the crime of aggression? Is it really true that, for instance, the 2007 judgment in the ICJ between Bosnia \& Herzegovina and Serbia on the matter of genocide was any less politically and emotionally charged than the dispute between the Democratic Republic of Congo and Uganda on aggression, adjudicated by the World Court little more than a year earlier?" ${ }^{19}$ Has not "the genocide word" been used lately with even more force than 'aggression'? Was not genocide called "the crime of crimes" by the ICTR? ${ }^{20}$

Further, even if it were true that aggression is committed only (or mainly) by states (see infra) - which necessitates implications at the highest governmental level - that might not be so unique. First of all: All acts of genocide that have been committed, or have allegedly been committed, in recent years have a clear state nexus. The genocide in Rwanda was planned and ordered by the then Government of Rwanda. The alleged genocide in Darfur appears to come under the responsibility of the Sudanese government, or at least that is the necessary conclusion of recent decisions by the Prosecutor and the Pre-Trial Chamber of the ICC. ${ }^{21}$ Secondly: It has been held by some commentators that an armed attack and an act of aggression can be committed also by a non-state armed group, be it al-Qaida or Hezbollah. ${ }^{22}$ For sure, there is no

${ }^{19}$ ICJ, Judgment, Application of the Convention on the Prevention and Punishment of the Crime of Genocide (Bosnia and Herzegovina v. Serbia and Montenegro), 26 February 2007; ICJ, Judgment, Armed Activities on the Territory of the Congo (Democratic Republic of the Congo v. Uganda), 19 December 2005, both available online at http://www.icj-cij.org, visited 16 January 2008.

${ }^{20}$ ICTR, Judgment (sentence), Jean-Paul Akayesu, Case No. ICTR - 96 - 4 - T, 2 October 1998, available online at http://www.ictr.org, visited 16 January 2008.

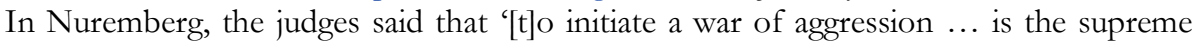
international crime ... [which] contains within itself the accumulated evil of the whole.' Cited from Benjamin B. Ferencz, 'The Crime of Aggression' in Gabrielle Kirk McDonald and Olivia Swaak-Goldman (eds) Substantive and Procedural Aspects of International Criminal Law: The Experience of International and National Courts (The Hague: Kluewer Law International, 2000) 37-62 at 37 and Robert Cryer, Håkan Friman, Darryl Robinson and Elizabeth Wilmshurst, supra note 10, at 267. Is the crime of aggression still the mother of all crimes, as it was in 1939? Most mass killings today take place in the context of internal armed conflict, in which there is no aggressor, per definition. Wilmshurst wisely asserts that 'there cannot be any need to engage in an abstract competition for the dreadful title of the worst international crime.' Ibid.

${ }^{21}$ ICC, Decision (Warrant for Arrest), Ahmad Harun, Pre-Trial Chamber, ICC-02/0501/07, 27 April 2007, p 5. Harun is charged with crimes against humanity and war crimes, not genocide, before the ICC, but the acts which are the subject of the prosecution are the same as those that some commentators would judge to constitute genocide.

${ }^{22}$ For that view, see Mark S. Stein, 'The Security Council, the International Criminal Court, and the Crime of Aggression: How Exclusive is the Security Council's Power to Determine Aggression?', 16 Indiana International and Comparative Law Review (2005) 1-36, at 4; Grant M. Dawson, 'Defining Substantive Crimes within the Subject Matter Jurisdiction of the International Criminal Court: What is the Crime of Aggression?', 19 New York Law School Journal of International and Comparative Law (2000) 413-452, at 444. Cf also Rolf Einar Fife, 'Criminalizing individuals for acts of aggression committed by states' in Human Rights and Criminal Justice for the Downtrodden: Essays in Honour of Asbjorn Eide 
state practice whatsoever for criminal responsibility for non-state aggression, and it might therefore be difficult or impossible to criminalize such conduct as aggression in the Rome Statute (it is, of course, already criminalized in many other ways). However, this notion is still significant for its implications on the idea that there is a necessary and unique state nexus for the crime of aggression.

(d) Gathering the evidence.

Hence, there are a number of more or less surmountable legal hurdles for foreign national prosecutions, most prominently personal immunity. A practical problem that national authorities might face is the lack of evidence. A state that wants to prosecute a foreign national may encounter difficulties in finding evidence of that person's involvement in the aggression. This holds true for all international crimes, but the crime of aggression is still a bit different, in that it is more likely that perpetrators will be far removed from the scene of the crime, as well as that much of the evidence will lie in protocols, minutes and other documents in governmental quarters, as the Nuremberg judgments bear out. Nevertheless, in some situations that involvement will be so obvious that a prosecution can take place even in the absence of such documentation. ${ }^{23}$

What would be the complementarity issues before the ICC? Well, by and large they would be the same as would normally arise before the Court for the other crimes. If a state is unable to prosecute because of immunities or other procedural bars, then complementarity could probably not be successfully raised as a bar to admissibility (even if that does not follow explicitly from the Statute). The same applies if the domestic authorities have been unable to acquire necessary evidence to prosecute. These issues have not been debated in the SWGCA.

An issue that was raised during the informal Princeton meeting of the Working Group is that a victorious nation might prosecute without due regard to the rights of the victim, or that, conversely, a 'victim' state might be intimidated by a more powerful state from prosecuting. Either of those eventualities might - perhaps, but for different reasons - justify an intervention by the ICC, and they might both be more likely in connection with a crime of aggression. ${ }^{24}$ However, both situations may appear with regard to other crimes, too, and the meeting felt that these problems could be dealt with within the existing language of the Rome Statute. ${ }^{25}$

(Leiden: Brill, 2003) 53-74, at 72. This, of course, builds on the assumption that the September $11^{\text {th }}$ attacks indeed constituted an armed attack (that could, but does not have to be inferred from SC Res 1368), and that 'armed attack' is the same thing as 'aggression', following Bengt Broms. Bengt Broms, 'The Definition of Aggression', 154 Recueil des Cours (1977) 301-399, at 370. Contra, Robert Cryer et al, supra note 10, at 267 and 274.

23 A legal-technical problem, when it comes to the criminalization in domestic law of the crime of aggression, is that the general principles in Part III of the Rome Statute, like Article 25(3)(f) on attempts, might not apply fully to the Crime of Aggression, as has been discussed in the SWGCA in quite some detail. See Report on Informal intersessional meeting of the Special Working Group on the Crime of Aggression, held at the Liechtenstein Institute on Self-Determination, Woodrow Wilson School, at Princeton University, New Jersey, United States, from 21 to 23 June 2004, ICCASP/3/SWGCA/INF.1, paras.20-27.

That is a problem that will likely be resolved by legislators, once the Rome Statute has been amended, but it will be resolved differently in different jurisdictions, since legislators have chosen different techniques to incorporate international crimes in their jurisdictions.

${ }^{24}$ Several commentators emphasize, though, that it was not the intention of the Statute to monitor the respect for the right to a fair trial and other human rights standards in domestic trials. Robert Cryer et al, supra note 10, at 129.

25 Supra footnote 6 , at paras. 25 and 26. 
The informal Princeton meeting also discussed the case where an act may fall under more than one heading. What if something is prosecuted nationally as a crime against humanity or a war crime when the same concrete acts - though viewed from another perspective, as an aggregate - might constitute an act of aggression? That possibility is also not unique for the crime of aggression; there are many examples from the jurisprudence of the international criminal tribunals where the same act might, for instance, constitute both a crime against humanity and a war crime. Article 20 (3) ICCSt. on ne bis in idem refers to the more concrete term 'conduct' rather than the abstract juristic concept of 'crime', ${ }^{26}$ and that was confirmed in the Thomas Lubanga Case, where the pre-trial chamber of the ICC referred to the conduct of Lubanga, not the crime, in its deliberation of complementarity. ${ }^{27}$

So, the general rules on admissibility in the Rome Statute would seem to apply without efforts to the crime of aggression (and, as we have seen, the same applies to other procedural issues relevant to domestic prosecutions). However, perhaps the process leading up to the determination of admissibility is more significant for aggression than for the other crimes. According to Article 53, the Prosecutor must assess complementarity before initiating an investigation and Article 17 provides that the Court shall consider the same factors. This will inevitably involve a certain amount of interaction between the Court and national authorities, which might be more significant for a crime that is not very established in international and domestic jurisprudence (see infra). But it is far from certain that such interaction will be possible, and that leads me over to the second scenario.

\section{Scenario II: The ICC cannot exercise jurisdiction in casu}

This is the situation where there is a provision on aggression, and that provision includes special conditions - such as a decision by the Security Council or some other organ - and such condition has not been met.

Under this scenario, the issue of complementarity will not arise, since the ICC will not be able to exercise jurisdiction. Instead, here it is domestic courts that might be complementing the ICC, as it were.

The issues discussed above that domestic authorities might face will be relevant here too, like immunities, the act of state doctrine and the political questions doctrine, and they will probably be even more acute, since in this situation the question is probably not where the suspect will be prosecuted but if she will be prosecuted at all, since the ICC will no longer be an alternative. Nevertheless, from a strictly legal perspective these issues will not be different under this scenario than under the former one.

The same goes for the issue of jurisdiction. I have, however, chosen to deal with it under this rubric, since it is connected to the problem of the Security Council - if I may put it like that - which is particularly relevant for this scenario, and which will be treated a bit later.

It shouldn't be necessary to inform the readers of this text that international law recognizes several grounds for criminal jurisdiction: territoriality, the nationality of the perpetrator as well as - more controversially - of the victim, national security and other vital national interests and universal interest - the principle of universality. Jurisdiction on the basis of the principle of nationality and the principle of territoriality are absolutely uncontroversial, at least if they

26 Supra footnote 6, at paras.30-31. The Review Conference will further have to deal with the fact that Article 20(3) at present does not cover the crime of aggression (ibid., at 29). That does not seem to be a problem for the situation discussed here, though.

27 ICC, Decision (Warrant of Arrest), Lubanga Dyallo, Pre-Trial Chamber 10 February 2006, ICC-01/04-01/06, paras.37-39. So, the situation could arise that a national court is trying a person for war crimes amounting to an indiscriminate bombing campaign that also constitutes an act of aggression that the ICC Prosecutor is looking into. 
coincide. That is, no state would protest if the aggressor state itself prosecutes persons responsible for an act of aggression that that state has committed. Further, jurisdiction by the victim state over the aggressor's nationals would probably not be challenged even if the relevant concrete conduct by that individual (such as an order) took place on the territory of the aggressor.

The interesting question is if domestic courts can go further. In the 1996 Draft Code of Crimes against the Peace and Security of Mankind, the International Law Commission (ILC) proposed in Article 8 that only the ICC and the home state of the aggressor state should have jurisdiction over the crime of aggression. That seems to be a more restricted view than the one I just presented. However, if one reads the Commentary to Article 8, one finds that it does not build on existing state practice. ${ }^{28}$ Except for a very general invocation of the principle par in parem imperium non habet, the Commentary only refers to what the Commission finds proper and practical. In fact, it appears, it was referring to what some members of the commission thought proper and practical. Hence, the ILC was in this particular instance involved in progressive (or perhaps retrogressive) development rather than codification of positive international law.

In fact, as shown by Nicolaos Strapatsas, the 1996 Draft Code of Crimes does not correspond to state practice. ${ }^{29}$ In addition to the countries that now have the crime against peace or the crime of aggression in their criminal codes - I will mention some of them infra - after WWII a number of Allied countries, and a couple of countries that had been on the side of the Axis powers, adopted laws for the prosecution of crimes against peace against the recent aggressors, and a couple of states, also did pursue such prosecutions. Furthermore, in addition to the Nuremberg tribunal, which was quasi-international - if you will - there were also, prosecutions in the US and French zones for the crime against peace, and neither of those countries had even been the subject of aggression by Germany, according to the Nuremberg tribunal.

I guess that many countries would be prone to say that if they are victims of aggression, they could assert jurisdiction too, just like several Allied powers did after WWII. They could base that either on the principle of territoriality - which might extend to the consequences of the individual crime of aggression, which takes effect on the territory of the victim state - or on the principle of security, i.e., that states have jurisdiction over crimes that affect their national security.

Is there also universal jurisdiction? Many commentators - like Yoram Dinstein - believe that the crime of aggression already is an international crime with individual responsibility, ${ }^{30}$ and that courts therefore may judge a national of a foreign state for that crime, even under universal jurisdiction. ${ }^{31}$ Others would be more cautious and say that given the lack of state practice apart

28 Yearbook of the International Law Commission, Volume II, Part II (1996) A/CN.4/SER.A/1996/Add.1 (Part. 2), p 30.

${ }^{29}$ Nicolaos Strapatsas, supra note 11, at 5-6.

30 Yoram Dinstein, War, Aggression and Self-Defence (Cambridge: Cambridge University Press, 4th ed., 2005), 123; Rolf Einar Fife, 'Criminalizing individuals for acts of aggression committed by states' in Human Rights and Criminal Justice for the Downtrodden: Essays in Honour of Asbjorn Eide (Leiden: Brill, 2003) 53-74, at 53; Irina Kuye MüllerSchieke, 'Defining the Crime of Aggression Under the Statute of the International Criminal Court', 14 Leiden Journal of International Law (2001) 409-430, at 414-415; Robert Cryer, supra note 10 , at 262 . That point is argued in detail also in the contribution to this volume by Muhammad Aziz Shukri.

31 Yoram Dinstein, War, Aggression and Self-Defence (Cambridge: Cambridge University Press, 4th ed., 2005), 145; Antonio Remiro Brotóns, 'Aggression, Crime of Aggression, Crime without Punishment', Working Paper No 10 (Madrid: Fundación para las Relaciones Intemacionales y el Diálogo Exterior (FRIDE), 2005), 16. See also Principles 1 and 2 of 'The Princeton Principles on Universal Jurisdiction', reprinted in Stephen Macedo (ed), Universal Jurisdiction: National Courts and the Prosecution of Serious Crimes Under International Law (Philadelphia: University of Pennsylvania Press, 2004) 18-25, at 21. See further the resolution adopted by the Institut de droit international in 2005, 'Universal 
from that post World War II it is difficult to confirm whether there is really universal jurisdiction. ${ }^{32}$ But a domestic institution that would like to exercise universal jurisdiction would probably invoke the Nuremberg precedent, as well as a number of domestic examples just alluded to.

As already mentioned, another issue that will be at the forefront under this scenario is the role of the Security Council. It is well-known that one of the most difficult issues in the discussions on the crime of aggression, probably the most difficult, is the role of the Council. Will the ICC be able to function independently of the SC or is it necessary that the Council determine that an act of aggression has occurred or otherwise agree to a prosecution before the Court may proceed $?^{33}$ During the discussions, organs other than the SC have been mentioned as

criminal jurisdiction with regard to the crime of genocide, crimes against humanity and war crimes', available at (visited 9 February 2009) http://www.idiiil.org/idiE/resolutionsE/2005 kra 03 en.pdf, which, however, explicitly does not address the crime of aggression, as well as 'The Cairo - Arusha Principles On Universal Jurisdiction In Respect Of Gross Human Rights Offences: An African Perspective', http://www.kituochakatiba.co.ug/cairo-arusha.htm, which only cover gross human rights abuses and similar offences, not the crime of aggression. (Both Internet addresses above visited 16 January 2008.) See also Claus Kreß, 'Universal Jurisdiction Over International Crimes and the Institut de droit international, Journal of International Criminal Justice (2006) 1-25, at 15, which suggests the presumption that there is universal jurisdiction for any crime under international customary law.

I will here leave aside the difficult and important issue whether universal jurisdiction can be exercised in absentia and, if so, to what degree. As is well-known, that was one of the key issues in the Arrest Warrant Case.

32 Giorgio Gaja, 'The Long Journey towards Repressing Aggression', in Antonio Cassese, Paola Gaeta and John R.W.D. Jones (eds), Rome Statute of the International Criminal Court (Oxford: Oxford University Press, 2002) 427-441, at 432.

33 The real problem, as many negotiators would see it (including this one), is how to pay respect to the SC as a body without vesting each permanent member with a veto. There is no magic formula on the table yet. In principle, one can approach it from either of two angles: 1. Accept that there will have to be some sort of affirmative decision by the SC, but make it as hard as possible for the Council to not agree to a prosecution and as easy for it as possible to say yes. Various ideas have been put on the table, including a proposal that the SC could give a 'green light' to prosecutions without having to pronounce itself on the substance, namely whether an act of aggression has occurred or not. To put the matter before the SC as late as possible in the proceedings is another option, since the pressure on the Council would be greater if the Prosecutor has already found there to be a prima facie case. Another theoretically possible way to get around the veto might be to seize upon the last words of 27(3) of the Charter, namely that a member of the Council that is a party to a dispute shall not participate in decisions under Chapter VI. The States Parties could in one way or another remind the Council of this. Of course, this assumes that a crime of aggression situation could be labelled a 'dispute' or a 'situation' under Chapter VI (see Articles 33 and 34 of the Charter) which is not certain.

2. Do not give the P5 (the permanent five members) a veto, but make it as hard as possible for the Court to proceed without an affirmative SC decision. The extra judicial filter through a 'Grand Pre-Trial Chamber' (my words) proposed by Belgium (ICC$\mathrm{ASP} / 5 / \mathrm{SWGCA} / \mathrm{WP} .1$ ) is one such means, another is to have a long waiting period before the Court may proceed in the absence of a SC decision.

One possible way to get around the objection that it is the SC that has the mandate to deal with aggression (Article 39 of the Charter) might be to accept, as 2a second best', a permissive decision by the UN General Assembly under the Uniting for Peace formula. The Uniting for Peace mechanism (GA Resolution 377 (V)) acknowledges the Council's primary responsibility, but gives the Assembly the possibility to deal with a matter if the Council 'fails to exercise its primary responsibility for the maintenance of international peace and security' (though not explicit Chapter VII powers). Hence, to avail oneself of this mechanism would not mean a new by-pass of the Council but merely the use of a procedure that has been established and continuously used for more than half a century. 
well, namely the UN General Assembly, the International Court of Justice and the ICC Assembly of States Parties. Nevertheless, since it is the Council that has been in the focus of the discussions, I, too, will focus on the possible role of this organ.

Now, can domestic prosecutions take place only after the Security Council has made a decision? To my knowledge, that issue has lately been discussed seriously by States Parties only informally, during the aforementioned 2004 inter-sessional meeting at Princeton, and even then not at any great length. The records of the meeting are a bit Delphic: 'It was emphasized that the issue of complementarity and admissibility was closely related to the definition of aggression and the role of the Security Council.' Some delegations found that a decision by the SC 'would not be needed for the application of national legislation on aggression.' However, '[o]ther delegations expressed the view that national legislation should be consistent with applicable international law, ${ }^{34}$ On its face, the latter statement seems superfluous; national legislation always has to conform to international law, or at least that is how we international lawyers would like to see things. However, for those who have followed the crime of aggression negotiations, phrases like 'consistency with applicable international law' are familiar code-words for a reference to Article 39 of the Charter which, in the view of some delegations, provides that it is only the SC that may determine when an act of aggression has occurred..$^{35}$

Most states that have found that the domestic authorities have prima facie jurisdiction - as I will deal with later on - will probably not feel duty-bound under international law to wait for a decision by the Council. However, some states have held that an individual crime of aggression has occurred only subject to a prior determination of the state act of aggression by the SC in accordance with article 39 of the UN Charter. According to one old proposal, the crime of aggression should be defined that way, namely in effect that an act of aggression is whatever the SC determines to be an act of aggression, and only that. That proposal has considerably less support now. ${ }^{36}$ At any rate, states who do not feel that Article 39 gives the SC global and

34 Supra footnote 6, paras.22 and 23 , respectively.

35 The formula in the Statute itself is 'consistent with the relevant provisions of the Charter of the United Nations' (Article 5(2)). See Vera Gowlland-Debbas, 'The functions of the United Nations Security Council in the International Legal System', in Michael Byers (ed), The Role of Law in International Politics: Essays in International Relations and International Law (Oxford: Oxford University Press, 2000) 277-314, at 298; Carrie McDougall, "When Law And Reality Clash - the Imperative of Compromise in the Context of the Accumulated Evil of the Whole: Conditions for the Exercise of the International Criminal Court's Jurisdiction over the Crime of Aggression', 7 International Criminal Law Review (2007) 277-333, at 278-279.

36 The legal argument for that view is weak, and doctrinal writers are generally quite sceptic, to use an understatement. Robert Cryer et al, supra note 10, at 278 (that section was written by Elizabeth Wilmshurst); Vera Gowlland-Debbas, supra note 35, at 299; Irina Kuye Müller-Schieke, 'Defining the Crime of Aggression Under the Statute of the International Criminal Court', 14 Leiden Journal of International Law (2001) 409-430, at 425-427; Mark S. Stein, 'The Security Council, the International Criminal Court, and the Crime of Aggression: How Exclusive is the Security Council's Power to Determine Aggression?’, 16 Indiana International and Comparative Law Review (2005) 1-36; Antonio Remiro Brotóns, 'Aggression, Crime of Aggression, Crime without Punishment', Working Paper No 10 (Madrid: Fundación para las Relaciones Intemacionales y el Diálogo Exterior (FRIDE), 2005), 14; D. D. N. Nsereko, 'Bringing aggressors to justice: From Nuremberg to Rome', 2 University of Botswana Law Journal (2005) 4-32, at 25-31; Carrie McDougall, supra note 35. See also Roger S. Clark, 'Rethinking Aggression as a Crime and Formulating Its Elements: The Final Work-Product of the Preparatory Commission for the International Criminal Court', 15 Leiden Journal of International Law (2002) 859-890, at 869-872; Constantine Antonopolous, Whatever Happened to Crimes against Peace?', 6 Journal of Conflict and Security Law (2001) 33-62, at 48-52; Niels Blokker, 'The Crime of Aggression and the United Nations Security Council', 20 Leiden Journal of International Law (2007) 867-894. One writer leaves the door open to 'the P5 view', however; Kriangsak Kittichaisaree, International Criminal Law (Oxford: Oxford University Press, 2001), 219-220. One particularly strong argument against 'the P5 view' is that it 
exclusive competence to determine acts of aggression will likely not feel obliged to implement such a definition of the crime in their domestic legislations.

The (old?) view that the SC determination is a part of the definition means that the Council's role is in the substance, i.e., a requisite of the crime. However delegations that today want to introduce a decision by the SC as a necessary requirement, generally hold such a decision as a procedural condition. That is, the role of the Council as contemplated by the SWGCA, is in jurisdiction, not in substance. Could it be argued that a decision by the SC is a procedural condition also for domestic prosecutions?

It would be quite difficult to argue that current international law requires that a SC decision is a procedural condition for States to prosecute the crime of aggression. There is some logic though deficient and built on mistaken premises, in my already implied view ${ }^{37}$ - to the claim that a SC determination is a part of the definition of the crime, that is, that such a determination is a substantive requirement. However, I cannot really see how one could formulate an argument that it would be an existing procedural requirement for domestic prosecutions. Either national legal systems have jurisdiction or they do not; general international law cannot possibly require that states defer to an institution created by a treaty. And the treaty itself - the UN Charter does not so provide, or at least I have not been able to find such a provision. Hence, if the basic jurisdiction were there, with regard to the crime of aggression, states would most likely not feel that international law requires them to wait for a SC determination before their national authorities may proceed. Moreover, many if not most legislators and judges would feel great unease at the idea of subjecting them to or involving them in such a political procedure.

Nevertheless, States could surely agree between themselves to restrict a right to exercise jurisdiction. Article 20(3) of the Rome Statute on ne bis in idem provides that '[n]o person shall be tried by another court for a crime referred to in article 5 for which that person has already been convicted or acquitted by the Court.' This is a restriction of States parties' right to prosecute, which goes beyond the common ne bis in idem provisions under human rights law, which only prohibit multiple prosecutions in the same domestic jurisdiction, not multiple prosecutions in different jurisdictions. ${ }^{38}$ Further, Article 15(5) of the 1991 Draft Code of Crimes proposed within square brackets, curiously enough - that any determination by the SC as to the existence of an act of aggression would be binding on national courts. Hence, it would not be totally unheard of, if states put such a restriction on themselves.

So, states parties to the Rome Statute can restrict the rights of domestic jurisdictions. All calls for caution with regard to this potentially politicised crime might be held to apply with greater force to foreign domestic jurisdictions than to the ICC, which is a creation of 108 states with 18 judges from 18 different countries. But then again, a restriction of an existing right to prosecute nationally would require a positive decision by states parties, and would have to be adopted in accordance with Article 121 of the Statute. That would be possible, but I leave it to

would impinge in the rights of the defendant since the ICC would be bound by the Use's decision (how could the right to 'determine the existence of ... an act of aggression' otherwise be exclusive?) and hence would be unable to defend herself on the ground that the act in question did not amount to an act of aggression. That problem has been pointed by many delegations (including my own from the year 2000), and has been noted also in literature. Irina Kuye Müller-Schieke, 'Defining the Crime of Aggression Under the Statute of the International Criminal Court', 14 Leiden Journal of International Law (2001) 409-430 at 427; Robert Cryer et al, supra note 10, 278.

${ }^{37}$ I here felt it necessary to depart from my chosen course not to speak de lege lata even in the main text. For references to the arguments against this deficient logic, see supra footnote 36 .

38 William A. Schabas, An Introduction to the International Criminal Court (Cambridge: Cambridge University Press, $2^{\text {nd }}$ ed, 2004), 89. 
others to determine whether it is likely. ${ }^{39}$ At any rate, such a restriction would only be binding interpartes.

In addition to a statutory restriction, one could also imagine a decision by the SC that would restrict the right to prosecute nationally. That would not be a decision under Article 16 of the Rome Statute, since Article 16 only pertains to the ICC, not to domestic courts. Instead, it would be a decision under the general competence of the Council under Chapter VII of the UN Charter. The SC has previously taken decisions with broad, horizontal effect. In Resolutions 1422 and 1487, the SC very controversially immunised all peacekeepers from the jurisdiction of the ICC. ${ }^{40}$ The Council has also adopted resolutions that have been called law-making, such as Resolutions 1373 and 1540. While these resolutions were welcomed widely for their political usefulness in the fight against terrorism, they have also been questioned as to their legal effect and as to the appropriateness of the Council taking on the role of adopting binding resolutions that apply not only to specific situations but have general, 'law-making' application. The SC could further pass situation-specific resolutions like Resolution 1497 on Liberia, which put peacekeepers in Liberia from non-parties to the Rome Statute under the exclusive jurisdiction of their home states, thus restricting the universal jurisdiction for international crimes by state. However, I believe it unlikely that it would be possible to muster the necessary majority in the SC to adopt a resolution limiting the right to prosecute for the crime of aggression.

So, it is unlikely that national authorities will become or feel duty-bound to refrain from proceeding in the absence of a Security Council decision. Nevertheless, states and domestic legal authorities might feel that they need some political legitimacy for the quite bold step of exercising jurisdiction over the most politically charged crime, the crime of aggression. A state might therefore unilaterally take a cautious approach, if lacking the backing of the Council. Caution in this situation can be required under judicial doctrine - such as the act of state or the political questions doctrine. But it might also be provided for by statutory law. The Swedish Code of Crimes requires, in general, that the Government give its consent to prosecution of foreign officials for conduct abroad. ${ }^{41}$ Such consent might be given more reluctantly if there is no green light from the SC.

The result of this discussion is that it is highly unlikely that it will be possible to limit what most would perceive to be legal freedom for states to prosecute for the crime of aggression. However, states - legislators or judges - might still feel a political or legal policy need for restraint.

I now come to the third case.

\section{Scenario III: There is no provision on the crime of aggression}

Under this scenario, the ICC can not act at all, and there is not even a definition of the crime in the Statute. In this situation, all of the aforementioned problems related to domestic prosecutions will apply, but there will be an added one, which we have not yet dealt with, that will feature very prominently, namely the lack of an agreement on what acts are covered by the crime: What is the definition of the crime? Some might even question whether aggression is an international crime under domestic jurisdiction. In addition, in those states that already have

\footnotetext{
${ }^{39}$ Gaja does not find it unlikely. Giorgio Gaja, 'The Long Journey towards Repressing Aggression', in Antonio Cassese, Paola Gaeta and John R.W.D. Jones (eds), Rome Statute of the International Criminal Court (Oxford: Oxford University Press, 2002) 427-441, at 440.

40 When Resolution 1487 was up for renewal in 2004, the US was unable to garner anything close to a majority, not counting the likely vetoes from some permanent members of the Council.

41 See in particular Sections 7 a and 7 b, Chapter 2, the Swedish Penal Code, available in English online at http://www.sweden.gov.se/sb/d/108/a/1536, visited 16 January 2008.
} 
provisions on the crime of aggression or similar crimes, judges might regret the lack of international authority from the Rome Statute to help them interpret the domestic provisions on those crimes.

Many if not all lawyers would probably say that the crime of aggression is already under domestic jurisdiction. The Crime of Aggression is on the book, as one of four crimes in Article 5 , and as mentioned the preamble claimed 'that it is the duty of every State to exercise its criminal jurisdiction over those responsible for international crimes'. ${ }^{42}$ The Court is currently prevented from exercising its jurisdiction with regard to this crime, but that does not mean that states are prevented from doing so.

This conclusion seems to have been corroborated recently in a judgment by the House of Lords. In that case, five peace activists, who had caused damage on a Royal Air Force base in the UK, had claimed that their acts were legally justified since they sought to prevent an alleged crime of aggression (the 2003 invasion of Iraq). The crux of the matter was therefore whether the crime of aggression was a crime under British law. The Law Lords held, very briefly, that there was indeed such a crime under international law, but that it was not a part of domestic law. ${ }^{43}$ The upshot seems to be that Great Britain and any other country has the authority to prosecute such crimes, but that the UK has not taken advantage of this opportunity, since it has not incorporated the crime of aggression into its criminal law. This is further confirmed by a number - admittedly not very high - of provisions in domestic statutes, the most famous one being Article 353 in the Russian Criminal Code, but also the criminal codes of Poland, Croatia, Germany and several other states. ${ }^{44}$

However, the domestic laws containing the crime of aggression are still few in number. States have probably felt that customary law might have to be clarified. Ten years of negotiations on the crime of aggression show that the matter is not universally agreed. Here are a few of the issues:

1. Does every illegal use of force constitute an act of aggression?

2. Do all acts of aggression by states correspond to crimes of aggression at the level of individuals? Is there a threshold?

42 Perhaps one should not draw to far-reaching conclusions from that preambular statement. See Robert Cryer et al, supra note 10, at 133. In general, on the possibility of exercising domestic jurisdiction over individual crime of aggression at present, see Antonio Cassese, 'On Some Problematical Aspects of the Crime of Aggression', 20 Leiden Journal of International Law (2007) 841-849.

${ }^{43}$ House of Lords, Judgment, $\mathrm{R} v$. Jones (Appellant) [2006] UKHL 16. The opinion observes that the core elements of the crime of aggression have been understood since 1945 and that current efforts to statutorily define it for purposes of the exercise of personal jurisdiction by the ICC do not obscure such historic elements. Lord Bingham's opinion cites, inter alia, the Preamble and Article 2(4) of the Charter of the United Nations, the Charters of the Nuremberg and Tokyo Tribunals, General Assembly Resolution 3314 (XXIX), and the 1954 and 1996 reports of the International Law Commission on the Draft Code of Offenses against the Peace and Security of Mankind. See ibid. at paras.11 - 18. See also Lord Hoffman's opinion at para.59. Lord Mance observes 'there is under public international law a crime of aggression which is, as history confirms, sufficiently certain to be capable of being prosecuted in international tribunals.' See ibid at para.99. A summary analysis of the case by Donald Ferencz, as well as the full text of the Jones judgment itself, may be found in 45 International Legal Materials (July 2006) 988-1014.

${ }^{44}$ See Helmut Gropengießer and Helmut Kreicker, Deutschland, in the series Albin Eser and Helmut Kreicker (eds), Nationale Strafverfolgung Völkerrechtlicher Verbrechen (Freiburg im Breisgau: Edition Juscrim, 2003) as well as other volumes in that series. See also the contribution by Astrid Reisinger Coracini in this volume and Alberto L. Zuppi, 'Aggression as International Crime: Unattainable Crusade or Finally Conquering the Evil?', 26 Penn State International Law Review (2007) 1-36, quoted from p 37 of draft, on file with author; Nicolaos Strapatsas, supra note 11, at 5. 
3. Does the crime of aggression only cover 'traditional' military action, such as military invasions or the other acts enumerated in Article 3 of the 1974 Definition of Aggression, or should the definition be open also to 'post-modern' means of coercion and destruction, such as computer network attacks (or cyber war), which can create just as much death and destruction as 'oldfashioned' kinetic attacks? ${ }^{45}$

Nevertheless, even in this far from clear-cut legal situation legislators and judges could conservatively and safely proceed from the Nuremberg precedent and the concept of war of aggression, which at least covers the penumbra of violent acts that are universally accepted as being acts of aggression. The House of Lords found that there were core elements of crime, understood since 1945. Another possibility would be to take the current state of the discussions in the Special Working Group as a starting point; recent records show that the differences have been narrowed down quite a bit. Courts and domestic legislators might not feel it necessary to wait for states parties do adopt a definition. It might suffice with an indication of what customary law says, supplied by the opinio juris expressed by the learned delegates of states participating in the Assembly of States Parties' SWGCA.

A preliminary conclusion here is that states might feel free to criminalize and prosecute for the crime of aggression at the domestic level, even without a provision on the crime of aggression in the Rome Statute, and the same applies to the event that there is such a provision, but the decision by the SC called for by such a hypothetical provision is not forthcoming. In other words, domestic legislators and authorities might feel authorised to criminalize and prosecute for crimes of aggression in situations where neither the ICC nor the Security Council has taken any form of decision on the matter. Whether that is likely to happen or not is impossible to say. The propensity to do so is not very wide-spread today, but things may change.

\section{Conclusion}

Some people find it dangerous to believe that the world could be changed through international criminal law. For sure, one should be realistic. But being realistic also means not to underestimate the power of law. ${ }^{46} \mathrm{Law}$ is (in general) a force for peace and justice, but it must always be exercised with prudence.

There are, as always, good arguments for domestic prosecutions. They are generally cheaper and quicker, and they might take place closer to the site of the crime. Furthermore, it is often better for a people that has been implicated in aggression and other crimes of the highest order, that it cleanse itself, through national trials.

There have been many calls for caution with regard to the criminalization and prosecution of the crime of aggression - as well as other international crimes, in particular system crimes - in both domestic and international fora. But it appears to me that caution should be even greater in the domestic than in the international arena. ${ }^{47}$ This applies both to foreign national courts and to courts of the state of nationality of the alleged perpetrator; a person responsible for aggression will most likely not be prosecuted in his or her own state while that person is in power, so the

\footnotetext{
${ }^{45}$ It is my view that cyber attacks may be covered by the word 'attack' in Article 3 of the Definition of Aggression, annexed to GA Res 3314 (XXIX).

${ }^{46}$ For this argument see, briefly as regards international criminal law, Frédéric Mégret,

'Three Dangers for the International Criminal Court', XII Finnish Yearbook of International Law (2001) 193-248, at 198.

47 Chandra Lekha Sriram, 'Universal Jurisdiction: Problems and Prospects of Externalizing Justice', XII Finnish Yearbook of International Law (2001) 47-70. The discussion in Frédéric Mégret, 'Three Dangers for the International Criminal Court', XII Finnish Yearbook of International Law (2001) 193-248 could also, mutatis mutandis, be applied to universal jurisdiction.
} 
prosecution will take place under another, new regime, which might have its reasons for not allowing a completely impartial trial. ${ }^{48}$

No doubt, many domestic courts and legal authorities will be able to handle prosecutions of the crime of aggression in a professional and impartial manner. Courts in many countries have displayed courage and integrity in difficult circumstances. Nevertheless, controversial cases can sometimes be dealt with in a more effective and legitimate manner in an international than in a domestic court. Further, many states that may wish to prosecute the crime of aggression will feel the need for support from the ICC through the interaction between the ICC and domestic courts that is called for by the principle of complementarity. The ICC might be taking over the case, but it might also just be overlooking the domestic process in order to assess the admissibility situation, after having made out a prima facie case for a crime aggression, and that might actually help domestic legal authorities in their own pursuit of the case. And even when national prosecutions are being carried out professionally and impartially, it will be useful to have the legal guidance that a definition in the Rome Statute and judicial practice from the Court can provide, which is particularly important for a crime that has not been developed in the rich jurisprudence from which the other international crimes benefit.

The SC may provide political backing, and will always have the freedom to do so, regardless of what provision the states parties to the Rome Statute will eventually adopt. However, the Council will not be available to provide legal guidance. The SC is not a court of law, and, at any rate, those states that are sceptical of the Security Council will probably never accept to have their freedom to prosecute circumscribed by the Council. The only viable alternative is to let the ICC do the job that was intended for it.

The practical outcome of this argument is, it appears to me, that it is very important that the states parties agree on a viable definition, and secondly also agree on a provision to let the ICC exercise jurisdiction. ${ }^{49}$ This would give the ICC an opportunity to perform its guiding role.

The domestic prosecution of the crime of aggression is not about protecting, or infringing on, another nation's sovereignty. It is a matter of balancing and accommodating different sovereign rights: those of the state that wants to exercise jurisdiction and those of the other states involved. As the much criticised but still interesting Lotus judgment of the Permanent Court of International Justice from 1927 makes clear, jurisdiction is about the potential collision of sovereign rights. On the one hand the right to exercise jurisdiction on one's own soil, on the other hand the right to protect one's nationals or the right to have one's sovereign acts respected. It seems to me that all states would have an interest in authorising an impartial arbiter to handle or overlook such conflicts, in particular when it comes to a crime in which the international interest is so eminent.

\footnotetext{
48 Some doubt that a new regime would be interested at all, since such a trial would implicate the whole nation. Antonio Remiro Brotóns, 'Aggression, Crime of Aggression, Crime without Punishment', Working Paper No 10 (Madrid: Fundación para las Relaciones Intemacionales y el Diälogo Exterior (FRIDE), 2005), 16.

49 On the current negotiations, see Claus Kress, 'The Crime of Aggression before the First Review of the ICC Statute, 20 Leiden Journal of International Law (2007) 851-865.
} 